\title{
Unijny system relokacji w sprawozdaniach Komisji Europejskiej. Ocena i perspektywy ${ }^{1}$
}

\begin{abstract}
Streszczenie: 26 września 2017 r. formalnie zakończył się okres obowiązywania decyzji o relokacji osób będących w oczywistej potrzebie ochrony międzynarodowej. Z przewidzianych 160 tysięcy, relokacji poddano do tego czasu nieco ponad 29 tysięcy osób. Przy zastosowaniu metody analizy prawnej oraz analizy decyzyjnej, w artykule podjęto próbę odpowiedzi na następujące pytania badawcze: (1) co było przyczyną odmowy dokonania relokacji przez niektóre państwa członkowskie?; (2) jakie działania podejmowała Komisja Europejska chcąc nakłonić państwa do wypełnienia zobowiązań prawnych?; (3) jakie konsekwencje pociąga za sobą odmowa dokonania relokacji osób, będących w potrzebie ochrony międzynarodowej?. W artykule analizie poddano cykliczne sprawozdania Komisji Europejskiej z funkcjonowania nadzwyczajnego, czasowego mechanizmu relokacji. W toku poprowadzonych rozważań wskazano przyczyny niewywiązywania się przez państwa członkowskie z prawnych zobowiązań oraz przyczyny braku woli dokonania rzeczywistej reformy polityki azylowej i imigracyjnej. Udowodniono, że wyrażone w traktatach zobowiązanie do wspólnych, solidarnych działań w obliczu kryzysów ustapiło miejsca partykularnym dążeniom do wzmocnienia ochrony terytoriów państwowych.
\end{abstract}

Słowa kluczowe: relokacja, Unia Europejska, sprawozdania Komisji Europejskiej

G dy 14 i 22 września 2015 r. państwa członkowskie Unii Europejskiej wyraziły zgodę na ustanowienie czasowego, nadzwyczajnego mechanizmu relokacji osób będących w potrzebie ochrony międzynarodowej ${ }^{2}$, wydawało się, że ujęta w Traktacie o funkcjonowaniu Unii Europejskiej zasada solidarności pozwoli na rozwiązanie skutków kryzysu migracyjnego. Uzgodniony mechanizm był bowiem w założeniu wyrazem europejskiej solidarności z uchodźcami (i osobami w sytuacji podobnej do uchodźstwa) oraz z tymi państwami członkowskimi, które zmagały się z masowym napływem osób wymagających ochrony międzynarodowej (w szczególności z Grecją i Włochami). Sprawozdania Komisji Europejskiej z wykonania postanowień ww. decyzji ukazały, że solidarność jest czysto deklaratywna. Potwierdził to już zresztą wcześniej sprzeciw państw członkowskich wobec propozycji KE w sprawie utworzenia stałego mechanizmu relokacji osób wymagających ochrony międzynarodowej.

Celem niniejszego artykułu jest ukazanie dotychczasowego funkcjonowania mechanizmu relokacji (nie przesiedleń) oraz określenie perspektyw dalszych działań UE wobec osób wymagających ochrony międzynarodowej, do pomocy którym państwa członkowskie są zobowiązane na mocy Konwencji dotyczącej statusu uchodźców z 1951 r. Chodzi

${ }^{1}$ Prace nad niniejszym tekstem zakończono 25 lutego $2018 \mathrm{r}$.

2 Na mocy decyzji 2015/1523 z 14 września i 2015/1601 z 22 września 2015 r. Szerzej na ten temat założeń czasowego systemu relokacji: Adamczyk, 2017, s. 47-54; Potyrała, 2016, s. 174 i n.; Potyrała, 2015, s. 33-52. 
o udowodnienie, że wyrażone w traktatach zobowiązanie do wspólnych, solidarnych działań w obliczu kryzysów ustąpiło miejsca partykularnym dążeniom do wzmocnienia ochrony terytoriów państwowych. Tym samym, propozycja reformy Wspólnego europejskiego systemu azylowego w oparciu o stały mechanizm relokacji jest niemożliwa do zaakceptowania przez państwa członkowskie i ustąpi miejsca mechanizmowi dobrowolnemu. W tym zaś uczestniczyć będą nieliczni członkowie UE.

\section{Funkcjonowanie nadzwyczajnego mechanizmu relokacji}

Uzgodnienia jakie zapadły we wrześniu 2015 r. zainicjowały funkcjonowanie mechanizmu, który objąć miał łącznie 160 tysięcy cudzoziemców wymagających ochrony międzynarodowej, przebywających we Włoszech i Grecji. Zobowiązanie do relokacji podjęły wszystkie państwa członkowskie z wyłączeniem Danii, Wielkiej Brytanii i Irlandii ${ }^{3}$, przy częściowym, 12-miesięcznym zawieszeniu obowiązku wykonania relokacji dla Austrii ${ }^{4}$ i Szwecji ${ }^{5}$. Mechanizm relokacji funkcjonować miał do 26 września $2017 \mathrm{r}$.

Gdy w październiku i listopadzie 2015 r. doszło do pierwszych przekazań osób z Włoch i Grecji, wydawało się, że nadzwyczajny mechanizm relokacji zadziała, a wrześniowe decyzje zostaną w całości wykonane, czym państwa członkowskie dowiodą rzeczywistego przywiązania do zasady solidarności i podziału odpowiedzialności. Piętnaście sprawozdań Komisji Europejskiej zaprezentowanych do września 2017 r., oceniających funkcjonowanie mechanizmu, uwidoczniło jednak poważne problemy i niechęć wielu państw członkowskich do wywiązania się z przyjętych na siebie zobowiązań.

Pierwsze sprawozdanie z funkcjonowania nadzwyczajnego mechanizmu relokacji przedstawione zostało przez Komisję Europejską w połowie marca 2016 r. tj. pół roku po decyzjach o utworzeniu systemu i pięć miesięcy po rozpoczęciu pierwszych relokacji. W tym okresie relokacji z Grecji i Włoch poddano zaledwie 937 osób wymagających ochrony międzynarodowej (Communication, 2016c, s. 2), co ukazuje wykres 1.

Powodem wolnego tempa relokacji było - zdaniem Komisji Europejskiej - niewystarczające zaangażowanie państw członkowskich $w$ ten proces (ibid., s. 6). Z jednej strony chodziło o państwa, które otwarcie w wątpliwość podawały legalność decyzji Rady z 22 września 2015 r. (Wegry i Słowacja, które wniosły do Trybunału Sprawiedliwości sprawy o kontrolę legalności ww. decyzji). Z drugiej strony, o państwa, których oficjalne stanowisko w sprawie relokacji uległo zmianie (Polska). W końcu o państwa, które zgłaszały gotowość relokowania, lecz pod określonymi warunkami, odnoszącymi

${ }^{3} \mathrm{~W}$ związku z postanowieniami protokołu dołączonego do traktatu lizbońskiego, choć władze Danii wyrazily wolę przyjęcia 1 tysiąca osób, a Irlandii - 4 tysięcy osób.

${ }^{4} \mathrm{Z}$ uwagi na gwałtowny wzrost obywateli państw trzecich na terytorium Austrii, na mocy decyzji Rady 2016/408 z 10 marca 2016 r. do 11 marca 2017 r. zawieszono obowiązek relokacji 30\% osób (tj. 1065) przypisanych Austrii w ramach kwot uzgodnionych we wrześniu $2015 \mathrm{r}$.

${ }_{5}$ Z uwagi na gwałtowny wzrost obywateli państw trzecich na terytorium Szwecji, na mocy decyzji Rady 2016/946 z 9 czerwca 2016 r. do 16 czerwca 2017 r. zawieszono obowiązki Szwecji jako państwa relokacji. 
Wykres 1. Liczba osób poddanych relokacji w okresie od października 2015 r. do 15 marca 2016 r.

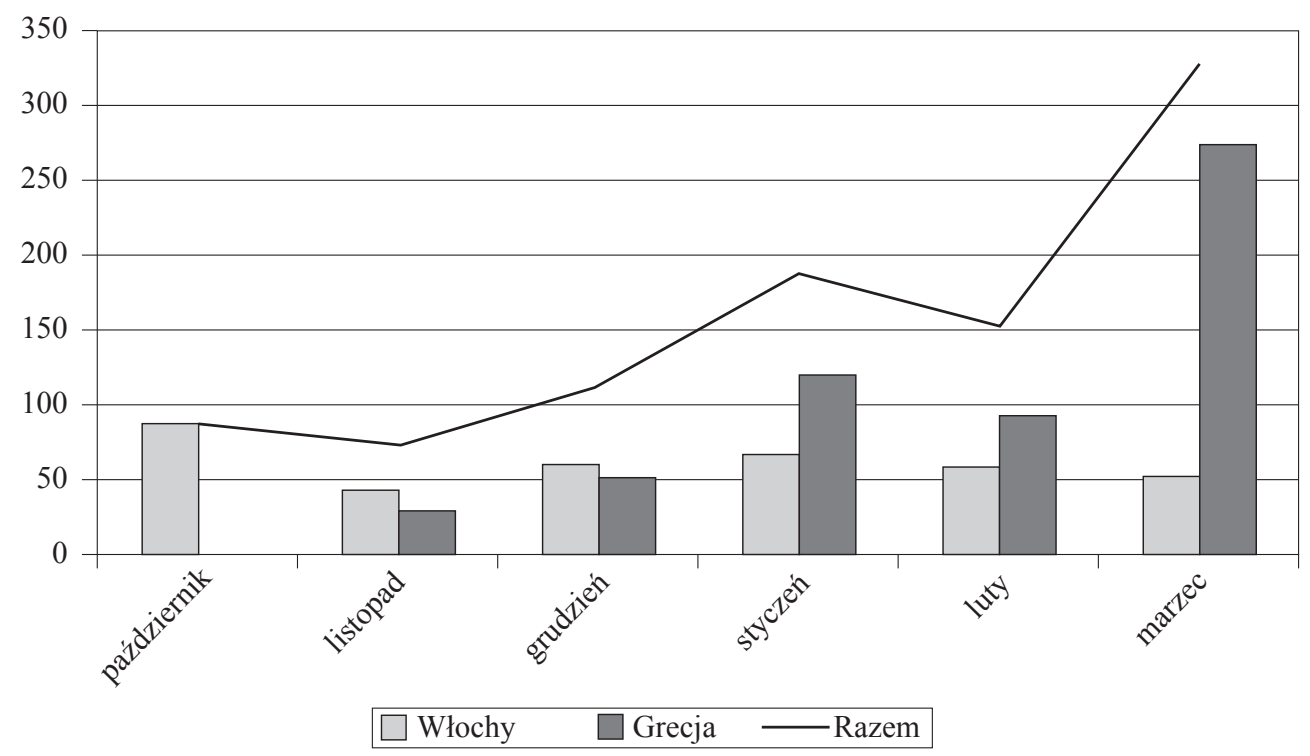

Źródło: Communication, 2016c, s. 6.

się np. do płci, wieku' ${ }^{6}$, statusu społecznego ${ }^{7}$ lub obywatelstwa osób mających być poddanymi relokacji (Bułgaria, Litwa, Łotwa). Wszystkie te państwa przywołując argument o nieskuteczności relokacji oraz argument o konieczności ochrony bezpieczeństwa wewnętrznego czy porządku publicznego - często pomimo wcześniejszych deklaracji - nie wyrażały gotowości przyjmowania cudzoziemców przebywających w Grecji lub Włoszech. Takie działania Komisja Europejska uznała za naruszenie obowiązku prawnego oraz za sprzeczne z duchem lojalnej wspótpracy (ibid., s. 11). Wzywała do wypełnienia zobowiązań, m.in. przez ograniczenie niewłaściwego korzystania z preferencji, a w przypadku odrzucenia wniosku o relokację - do wskazania szczegółowego uzasadnienia.

Warto jednak zwrócić uwagę, że wolne tempo relokacji wynikało również z prowadzenia dodatkowych kontroli bezpieczeństwa, nieodzownych po atakach terrorystycznych w Paryżu w listopadzie 2015 r. Niektóre państwa członkowskie postulowały konieczność prowadzenia wywiadów z osobami kwalifikowanymi do relokacji czy pobrania odcisków palców takich osób. Komisja Europejska postulowała zatem o przyspieszenie procedur bezpieczeństwa i ich wykonywanie w czasie nie dłuższym niż 7 dni. Podnosiła także konieczność szybkiej - tzn. nie dłuższej niż tydzień - reakcji na wezwania z Grecji i Włoch do relokacji konkretnych osób. Co więcej, dążąc do terminowego wykonania zobowiązań wynikających z decyzji Rady z 14 i 22 września 2015 r. i relokacji 160 tysięcy osób, Komisja wezwała państwa do dokonywania relokacji co najmniej 5679 osób miesięcznie (ibid., s. 24).

${ }^{6}$ Dla przykładu, problem dotyczył relokacji osób małoletnich pozostających bez opieki, do relokacji których „państwa członkowskie są niechętnie nastawione” (Communication, 2016c, s. 7).

${ }^{7}$ Państwa członkowskie były niechętne przyjmowaniu samotnych mężczyzn. 
12 kwietnia 2016 r. Komisja Europejska przedstawiła drugie sprawozdanie ukazujące osiagnięcia i problemy relokacji. Jednoznacznie jako niesatysfakcjonujacy oceniła dotychczasowy proces przekazywania osób wymagających ochrony międzynarodowej, przebywających w Grecji i we Włoszech. Zamiast zakładanych w pierwszym sprawozdaniu blisko 5700 przekazań, w okresie sprawozdawczym relokacji poddano zaledwie 208 osób: 46 z Grecji i 162 z Włoch (Report, 2016, s. 3). Wynikało to m.in. z braku działań ze strony władz Austrii ${ }^{8}$, Chorwacji, Polski, Republiki Czeskiej, Słowacji, Słowenii i Węgier, które nie przesłały do Grecji i/lub Włoch oficjalnych zobowiązań o gotowości do dokonania relokacji. Spowolniony proces relokacji wynikał również z przewlekłych procedur relokacyjnych, w szczególności zbyt długiego czasu odpowiedzi na wezwania do relokacji ze strony Grecji i Włoch. Był to zarzuty kierowany do większości państw członkowskich. Za istotne dla poprawy procesu relokacji, KE uznała zatem skrócenie czasu odpowiedzi na wezwania, a także poprawę procesu rejestracji cudzoziemców napływających do Grecji i Włoch.

Trzecie sprawozdanie z realizacji założeń nadzwyczajnego mechanizmu relokacji Komisja Europejska zaprezentowała 18 maja 2016 r. Podobnie jak we wcześniejszych raportach, podniosła zarzut zbyt wolnego tempa relokacji, która w okresie od 12 kwietnia 2016 r. do chwili opublikowania trzeciego sprawozdania, objęła zaledwie 355 osób, z których 294 relokowano z Grecji, 61 z Włoch (Communication, 2016g, s. 3). Jak w poprzednich sprawozdaniach, za powód KE uznała niewypełnianie lub unikanie wypełniania zobowiązań wynikających z decyzji Rady z września 2015 r. Władzom Bułgarii, Estonii i Republiki Czeskiej zarzuciła odrzucanie wniosków o relokację bez uzasadnionych powodów lub z powodów innych niż wskazane w ww. decyzjach z $2015 \mathrm{r}$. Polsce - zawieszenie procedury relokacji wbrew wcześniej złożonym zobowiązaniom gotowości'. Austrii, Słowacji i Węgrom - brak jakichkolwiek działań, choć - co Komisja zauważyła już w pierwszym sprawozdaniu - wniesienie przez dwa ostatnie państwa sprawy do TS nie miało skutku zawieszającego, a zatem relokacja powinna być przez władze Słowacji i Węgier wykonywana. Odnosząc się do braku współpracy ze strony tych państw, KE zastrzegła sobie prawo do podjęcia działań w sytuacji, gdy państwa członkowskie nie wywiązują się ze swoich zobowiązań (ibid., s. 11). Nie sprecyzowała jednak na czym działania te mają polegać.

Pozytywnie Komisja Europejska oceniła natomiast aktywność władz Belgii i Malty, które w odpowiedzi na wcześniejsze wezwania, wyraziły wolę przyjęcia małoletnich bez opieki. Podobnie, z aprobatą KE przyjęła aktywność Finlandii, Luksemburga, Malty i Słowenii, zmierzającą do skrócenia do dwóch tygodni czasu odpowiedzi za wezwania do relokacji ze strony Grecji i Włoch.

15 czerwca 2016 r. Komisja Europejska przedstawiła wnioski zawarte w czwartym sprawozdaniu $\mathrm{z}$ funkcjonowania mechanizmu relokacji osób wymagających ochrony międzynarodowej. Wnioski te nie napawały optymizmem. Osiagnięcie „docelowych kwot w ramach programu relokacji, określonych w decyzjach Rady" Komisja uznała za

${ }^{8}$ Choć Austria korzystała przez 12 miesięcy z czasowego zawieszenia relokacji w odniesieniu do $30 \%$ kwoty przypisanej na mocy decyzji z września 2015 r., to miała obowiązek w tym okresie prowadzić relokację pozostałych osób.

${ }^{9}$ Chodziło o zawieszenie przez Polskę rozpatrywania 73 wniosków z Grecji, pomimo zobowiązania wyrażonego przez polskie władze 16 grudnia $2015 \mathrm{r}$. 
dalekie, podkreślając że zobowiązania wypełniono zaledwie w dwóch procentach (Communication, 2016d, s. 3). Przy czym pięć państw członkowskich (tj. Austria, Chorwacja, Polska, Słowacja i Węgry) do czerwca 2016 r. nie relokowało ani jednej osoby, siedem państw (tj. Belgia, Bułgaria, Hiszpania, Litwa, Niemcy, Republika Czeska i Rumunia) dokonało relokację zaledwie 1\% docelowych kwot cudzoziemców (ibid.).

Opóźnienia w realizacji założeń relokacyjnych wynikały jednak nie tylko z samej niechęci niektórych państw wobec przyjmowania cudzoziemców, co przejawiało się w odrzucaniu wniosków Grecji i Włoch bez przedstawienia uzasadnionych przyczyn lub z przyczyn innych niż określone w decyzjach Rady z 2015 r. Powodem były również wydłużające się postępowania sprawdzające. Postępowania prowadzone ze względów bezpieczeństwa, zamiast zakładanych przez KE dwóch tygodni, przekraczały niejednokrotnie wskazany w decyzjach Rady okres dwóch miesięcy. Kolejnym czynnikiem wpływającym na spowolnienie relokacji było rozproszenie przybywających do Grecji cudzoziemców ubiegających się o ochronę, po całym terytorium tego państwa. Władze Grecji zobowiązały się zatem do utworzenia trzech centrów relokacji, aby „scentralizować liczne procedury" (ibid., s. 8). Wolne tempo relokacji wynikało również z napływu nowych osób, w szczególności do Włoch, co prowadziło do niewydolności włoskich hotspotów. W konsekwencji, KE postulowała utworzenie mobilnych punktów przyjęć, a także zwiększenie koordynacji działań krajowych instytucji, co miało przyspieszyć procedury relokacji.

Niezależnie od przyczyn, wolne tempo relokacji pod znakiem zapytania stawiało terminowe wykonanie decyzji Rady ustanawiających nadzwyczajny, czasowy mechanizm relokacji. Komisja Europejska ponowiła zatem ostrzeżenie o prawie do podjęcia działań (bez ich precyzowania) w sytuacji niewywiązywania się przez państwa członkowskie ze zobowiązań (ibid., s. 11).

Podobnie jak czwarte sprawozdanie Komisji Europejskiej wskazywało problemy w wypełnianiu postanowień decyzji Rady z 2015 r., również w piątym sprawozdaniu z lipca 2016 r. ocena funkcjonowania nadzwyczajnego mechanizmu relokacji oraz ocena działań podejmowanych przez państwa członkowskie, była negatywna. Stanowisko Polski i Węgier nie uległo zmianie, Austria również nie podjęła wykonania obowiązku relokacji w odniesieniu do osób, w stosunku do których nie korzystała z rocznego odroczenia. Nadal niektóre państwa członkowskie odrzucały greckie i/lub włoskie wnioski o relokację, bez uzasadnienia powodów odmowy lub wskazując powody inne niż przewidziane w decyzji Rady z września 2015 r. Problemem pozostawały odmowy relokacji osób nieletnich bez opieki - od października 2015 r. relokowano jedynie 29 takich osób z Grecji (Communication, 2016b, s. 5).

Nieco lepiej prezentowała się współpraca państw w zakresie przekazywania ekspertów ds. azylu oraz tzw. mediatorów kulturowych, którzy wspomóc mieli służby greckie i włoskie w przyjmowaniu i rejestracji napływających cudzoziemców. Gotowość udostępnienia wsparcia osobowego wyraziły władze Austrii, Chorwacji, Francji, Hiszpanii, Holandii, Litwy, Łotwy, Malty, Niemiec, Polski, Republiki Czeskiej, Rumunii, Szwecji i Wielkiej Brytanii (ibid., s. 6), a także Norwegii i Szwajcarii, które zadeklarowały wolę uczestnictwa w unijnym nadzwyczajnym mechanizmie relokacji. Pozytywnie KE odniosła się również do poprawy zdolności służb greckich w zakresie rejestracji cudzoziemców i rozpatrywania wniosków azylowych. Skrytykowała jednak brak działań na 
rzecz utworzenia centrów relokacji - z trzech, do uruchomienia których zobowiązały się władze greckie, do lipca 2016 r. utworzono tylko jedno. W przypadku Włoch, Komisja ponownie wezwała do utworzenia dodatkowych hotspotów oraz mobilnych punktów przyjęć. Za wymagającą poprawy KE uznała zdolność służb włoskich do rejestracji osób przybywających i rozpatrywania wniosków o ochronę. W tym miejscu warto zwrócić uwagę na problem podstawowy. Włoskie służby graniczne i azylowe nie były zdolne do sprawnego przyjmowania i rejestracji osób napływających oraz rozpatrywania wniosków azylowych. Jednocześnie Włochy odmawiały pozostałym państwom członkowskim, do których relokowani mieli być cudzoziemcy, prawa przeprowadzania dodatkowych postępowań sprawdzających. To nie tyle spowalniało, co wręcz blokowało proces relokacji. Potencjalne państwa relokacji powoływały się bowiem na konieczność zagwarantowania bezpieczeństwa i porządku wewnętrznego, odmawiając przyjmowania osób, które nie zostały przez krajowe służby zweryfikowane. Problem potęgowało niejasne stanowisko Komisji Europejskiej, która ograniczyła się do wezwania wszystkich państw do poszukiwania odpowiednich rozwiązań (por.: ibid., s. 9).

Szóste sprawozdanie w sprawie funkcjonowania mechanizmu relokacji, zaprezentowane 28 września 2016 r., zawierało wnioski oceniające roczne funkcjonowanie systemu. Nie odnotowano znaczącego postępu w tempie relokacji, a w konsekwencji w wykonaniu zobowiązań wynikających z decyzji Rady z września 2015 r. Bo choć sukcesywnie wzrastała liczba osób poddanych relokacji (por. wykres 2), to trudno było mówić o sukcesie. W połowie okresu obowiązywania decyzji Rady z września 2015 r. ze 160 tysięcy osób, które miały być relokowane, przejęto odpowiedzialność zaledwie za 5651 osób, z których 4455 przejęto z Grecji, a 1196 z Włoch (Communication, 2016f,

Wykres 2. Liczba osób poddanych relokacji w okresie od października 2015 r. do 28 września 2016 r.

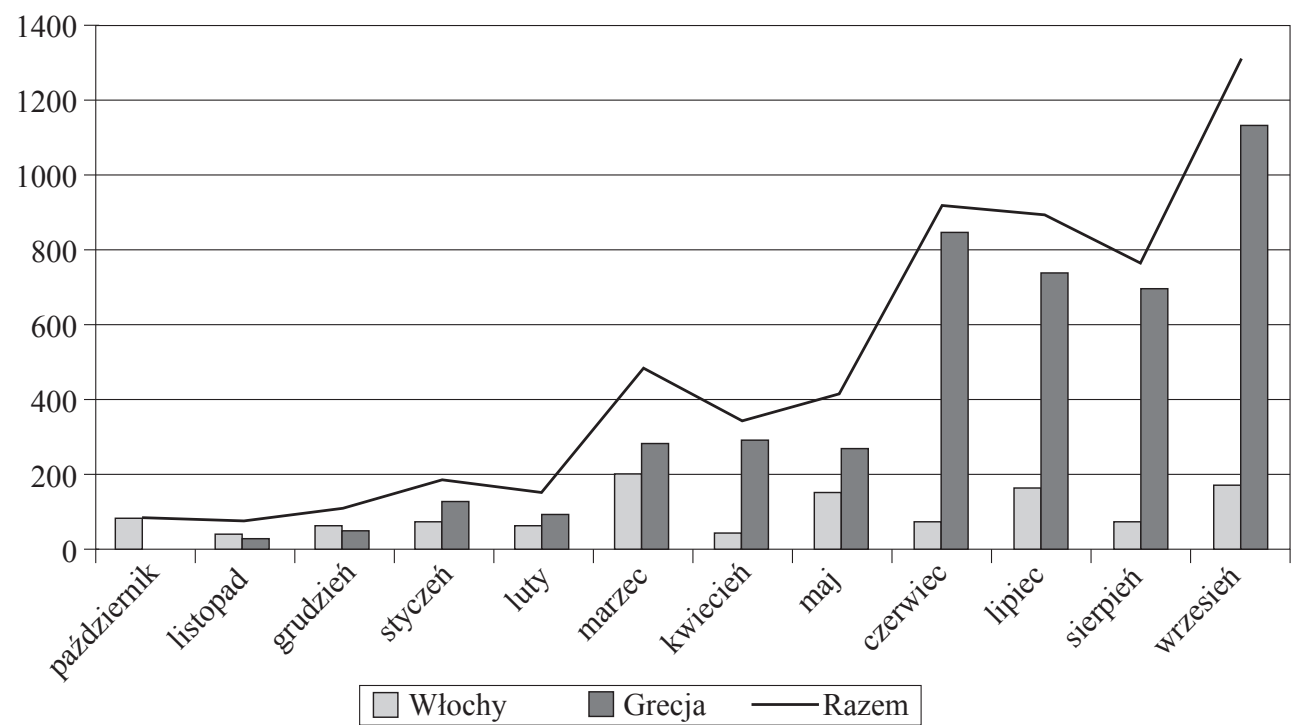

Źródło: Report, 2016f, s. 5. 
s. 2). Jak określiła sama Komisja: „osiągnięte rezultaty nie są proporcjonalne do poczynionych zobowiązań ani do skali wyzwań, którym należy sprostać” (ibid., s. 15).

Uwzględniając występujące trudności, Komisja pozytywnie oceniła zobowiązania podjęte przez władze Niemiec (do comiesięcznej relokacji 1000 osób w równej liczbie z Grecji i Włoch) oraz Belgii (do comiesięcznej relokacji 200 osób z Grecji i 100 osób z Włoch). Równie pozytywnie KE odniosła się do comiesięcznych zobowiązań składanych przez władze Estonii, Litwy, Luksemburga i Łotwy, a także Finlandii, Francji, Holandii i Rumunii. Nawet niewielkie formalne zobowiązania, złożone w okresie sprawozdawczym przez Liechtenstein i Norwegię do przyjęcia odpowiednio 10 i 20 osób, zostały zauważone przez Komisję Europejską i wskazane jako wzór działania.

Szóste sprawozdanie było kolejnym, w którym Komisja Europejska wskazała brak współpracy ze strony władz Austrii, Polski i Węgier. Odnotowała także wysoki współczynnik odrzucania wniosków o relokację ze strony Republiki Czeskiej i Słowacji (ponad $50 \%$ ). Władze obu państw jako oficjalny powód odmowy dokonania relokacji wskazywały brak dokumentów tożsamości lub dokumentów podróży. Można jednak uznać, że był to jedynie pretekst do uniknięcia konieczności przyjmowania cudzoziemców, gdyż państwa te - podobnie jak Polska - w ramach Grupy Wyszehradzkiej, prezentowały wyraźne stanowisko sprzeciwiające się relokacji, uznając ją za rozwiązanie nieefektywne i zagrażające bezpieczeństwu państw i porządkowi publicznemu. Pomimo ewidentnego naruszania prawnych zobowiązań przez wskazane państwa, po raz kolejny Komisja Europejska ograniczyła się jedynie do ich wymienienia w sprawozdaniu i wezwania do podjęcia zobowiązań i regularnego przeprowadzania relokacji. Zapowiedziała jedynie - identycznie jak w sprawozdaniu drugim, trzecim, czwartym i piątym - „prawo do podjęcia działań w sytuacji, gdy państwa członkowskie nie wywiązują się ze swoich zobowiązań" (ibid., s. 16). Ostrzeżenie wyrażone kolejny raz traciło jednak na znaczeniu i nie przyczyniło się do pełnego wykonania zobowiązań przez państwa członkowskie.

W konsekwencji, w datowanym na 9 listopada 2016 r. siódmym sprawozdaniu Komisja Europejska odnotowała całkowitą liczbę osób relokowanych od października $2015 \mathrm{r}$. na poziomie zaledwie 6925 osób, z których 5376 relokowano z Grecji, a 1549 z Włoch (Communication, 2016e, s. 2). Z jednej strony, Komisja odnotowywała pozytywne aspekty w funkcjonowaniu mechanizmu relokacji. Podkreślała starania służb greckich prowadzące do zwiększenia liczby rejestrowanych cudzoziemców, a także aktywność Francji, Holandii i Finlandii, które przyjęły największą liczbę osób. Podobnie pozytywnie oceniła zgodę władz włoskich na wprowadzenie dodatkowych wyjątkowych kontroli bezpieczeństwa, o które wnioskowały inne państwa członkowskie. Z drugiej strony, KE wskazywała po raz kolejny brak aktywności Austrii, Polski i Węgier, a także Republiki Czeskiej i Słowacji, które w okresie sprawozdawczym nie podjęły zobowiązań i nie dokonały relokacji. I znów, jak w poprzednich sprawozdaniach, odnosząc się do niewypełniania lub nienależytego wypełniania zobowiazzań przez państwa członkowskie, Komisja wskazała prawo do podjęcia działań (por.: ibid., s. 17), bez ich precyzowania, bez odniesienia do traktatów, bez realizacji zapowiedzi. Ograniczyła się jedynie do przesłania pism do państw członkowskich, przypominając o ciążących na nich obowiązkach.

Ósme sprawozdanie z 8 grudnia 2016 r. wskazało trend wzrostowy w liczbie osób poddanych relokacji, co nie zmieniło faktu, że od października 2015 r. do innych państw członkowskich relokowano łącznie zaledwie 8162 cudzoziemców przebywających 
w Grecji i we Włoszech (Communication, 2016a, s. 2). Pomimo zaangażowania ośmiu państw członkowskich (Estonii, Francji, Holandii, Irlandii, Łotwy, Niemiec, Portugalii, Słowacji) oraz Norwegii i Szwajcarii w proces relokacji, brak aktywności ze strony Austrii, Polski, Republiki Czeskiej i Węgier oraz nienależyte wykonywanie zobowiązań przez pozostałe państwa członkowskie spowalniały proces relokacji. Zdaniem Komisji, usprawnienie procesu wymagało comiesięcznego przekazywania co najmniej 2000 osób z Grecji i 1000 osób z Włoch, a od lutego 2017 r. co najmniej 3000 osób z Grecji i 1500 z Włoch (ibid., s. 9). Odmowy dokonania relokacji konkretnych osób powinny być należycie uzasadniane, a wymiana informacji nt. powodów odmowy powinna odbywać się za pośrednictwem Europolu lub specjalnego kanału wymiany informacji, oferowanego przez policję grecką.

Ósme sprawozdanie było pierwszym, w którym Komisja Europejska wskazała, iż w razie dalszego niewykonywania lub nienależytego wykonywania zobowiązań wynikających z decyzji Rady z września 2015 r., skorzysta z uprawnień przysługujących jej na mocy traktatów.

W dziewiątym sprawozdaniu, zaprezentowanym w lutym 2017 r. po raz kolejny Komisja Europejska podkreśliła zaangażowanie większości państw członkowskich w wykonanie celów określonych w decyzjach Rady z września 2015 r., ale była daleka od optymizmu. Wskazała, że wypełnienie postanowień do końca okresu obowiązywania decyzji o mechanizmie relokacji, wymaga regularnego składania zobowiązań i dokonywania relokacji przez wszystkie państwa członkowskie. Tymczasem przez cały styczeń 2017 r. relokacją objęto zaledwie 1131 osób z Grecji i 551 z Włoch (Report, 2017d, s. 3). Wynikało to m.in. z niezadowalajacej postawy Austrii, Polski i Węgier. Austria i Węgry nie podjęły żadnych zobowiązań i nie dokonały relokacji ani jednego cudzoziemca z Grecji lub Włoch. Polska zaś, wbrew deklaracji ze stycznia 2016 r. (Rozporzqdzenie, 2016, par. 2.1), utrzymywała zawieszenie procedur relokacyjnych ${ }^{10}$. KE w sprawozdaniu skrytykowała również brak aktywności władz Republiki Czeskiej, które od maja $2016 \mathrm{r}$. nie dokonały przyjęć w ramach relokacji. Wzywając do intensyfikacji działań na rzecz relokacji osób wymagających ochrony międzynarodowej, KE podkreśliła zaangażowanie Europolu w przygotowanie i planowane prowadzenie dodatkowych, wyjątkowych kontroli bezpieczeństwa. Zdaniem Komisji, takie dodatkowe kontrole pozwolą zwiększyć zaufanie państw członkowskich do systemu relokacji. Za konieczne po raz kolejny KE uznała ustanowienie dodatkowych hotspotów we Włoszech, gdyż cztery działające w okresie sprawozdawczym (tj. Lampedusa, Pozzallo, Taranto, Trapani) okazały się niewystarczające do przyjęcia imigrantów i dokonania ich rejestracji na potrzeby systemu relokacji.

Co najważniejsze, w sprawozdaniu z lutego 2017 r. Komisja Europejska wskazała wyraźnie, że w sytuacji braku wymiernych postępów w realizacji obu decyzji Rady z września 2015 r., „Komisja nie zawaha się skorzystać z uprawnień nadanych jej na mocy traktatów" (ibid., s. 12). Była to zasadnicza zmiana w porównaniu z wcześniejszymi sprawozdaniami, w których poza stwierdzeniem wolnego tempa relokacji oraz braku

${ }^{10}$ Możliwość relokacji cudzoziemców z Grecji i Włoch negatywnie zaopiniował Międzyresortowy Zespót ds. zapewnienia bezpieczeństwa $w$ procesie przesiedleń i relokacji cudzoziemców, odmawiając rekomendacji relokowania 65 osób z Grecji i 35 osób z Włoch z uwagi na brak spełnienia kryterium bezpieczeństwa. 
zaangażowania niektórych państw członkowskich, Komisja wskazywała tylko prawo do podjęcia działań.

Ostrzeżenie jednak nie poskutkowało. Uznając czasowy mechanizm relokacji za kluczowy element unijnej odpowiedzi na kryzys migracyjny, w dziesiątym sprawozdaniu z marca 2017 r. Komisja Europejska nadal zwracała uwagę na wolne tempo relokacji, która do końca lutego 2017 r. objęła jedynie 14\% osób podlegających mechanizmowi. Paradoksalnie zabrzmiało zatem uznanie mechanizmu relokacji za praktyczny przejaw odpowiedzialności i solidarności (Report, 2017e, s. 2) państw członkowskich w obliczu kryzysu migracyjnego. W praktyce bowiem członkowie UE solidarności okazać nie potrafili. W szczególności, Austria, Polska i Węgry konsekwentnie odmawiały przejęcia odpowiedzialności za osoby wymagające ochrony, przebywające zarówno w Grecji, jak i we Włoszech, podobnie jak Republika Czeska. Bułgaria, Chorwacja i Słowacja, które wypełniły zobowiązania wobec Grecji zaledwie w 1-2\% (ibid., s. 4), zaś w odniesieniu do Włoch - żadnej osoby nie relokowały Bułgaria, Estonia, Irlandia, Litwa i Słowacja. $\mathrm{Z}$ tego względu za kluczową KE uznała regularność relokacji oraz natychmiastowe jej rozpoczęcie przez wskazane wyżej państwa.

Komisja odniosła się przy tym do wysuwanego przez państwa członkowskie argumentu o braku możliwości relokacji z uwagi na zagrożenie dla bezpieczeństwa i porządku wewnętrznego. Chodziło w szczególności o stanowisko prezentowane przez przedstawicieli Grupy Wyszehradzkiej, którzy podnosili brak możliwości przyjęcia osób w ramach systemu relokacji z uwagi na konieczność ochrony własnych obywateli i wyeliminowanie zagrożenia terrorystycznego, powiązanego - ich zdaniem - z ruchami migracyjnymi. Zwracali uwagę, że najważniejszy element systemu relokacji, tzw. hotspoty (punkty recepcyjne rozlokowane na granicach zewnętrznych UE) nie funkcjonują na tyle dobrze, aby rozdzielić uchodźców i osoby uprawnione do uzyskania ochrony od imigrantów ekonomicznych oraz osób stanowiących zagrożenie dla bezpieczeństwa państw UE. Uwzględniając powyższe, w dziesiątym sprawozdaniu Komisja Europejska podkreśliła konieczność wzmożenia wysiłków władz włoskich oraz greckich na rzecz szczegółowej rejestracji przybywających cudzoziemców. W szczególności postulowała o umożliwienie Europolowi przeprowadzania dodatkowych wywiadów z osobami mającymi kwalifikować się do relokacji, a także o zwiększenie liczby urzędników migracyjnych uczestniczących w procedurze identyfikacji osób przybywających.

$\mathrm{Na}$ opóźnienia $\mathrm{w}$ relokacji oraz na zbyt małe zaangażowanie państw w przejmowanie odpowiedzialności za osoby wymagające ochrony międzynarodowej KE ponownie zwróciła uwagę w sprawozdaniu jedenastym, zaprezentowanym w kwietniu $2017 \mathrm{r}$. Z jednej strony, Komisja Europejska doceniła wkład Niemiec, Francji i Holandii w relokowanie największej liczby osób, odpowiednio: 3511, 3157 i 1636 (Report, 2017a, s. 3), podobnie jak zaangażowanie władz Malty i Finlandii, które wypełniły zobowiązania w całości. Z drugiej, podkreśliła, że Austria, Polska i Węgry konsekwentnie odmawiają relokowania, a Republika Czeska wstrzymała relokację w 2016 r. (co oznaczało, że przyjęła na swoje terytorium mniej niż 1\% osób, które przyjąć powinna). Podobnie, Bułgaria, Chorwacja i Słowacja relokowały zaledwie $2 \%$ osób, do przyjęcia których zobowiązane zostały na mocy decyzji z września $2015 \mathrm{r}$.

Sytuacja nie zmieniła się znacząco w ciągu miesiąca. 16 maja 2017 r. Komisja Europejska opublikowała dwunaste już sprawozdanie w sprawie relokacji i przesiedlenia 
osób, będących „w oczywistej potrzebie międzynarodowej ochrony”. Wśród państw członkowskich Unii Europejskiej, uczestniczących formalnie w systemie, trzy - Austria, Polska i Węgry, do 12 maja 2017 r. nie wykonały relokacji w odniesieniu do żadnej osoby. Zdaniem Komisji Europejskiej to „naruszenie prawnych zobowiązań” (Report, 2017 g, s. 3). W raporcie znalazła się zatem wyraźna zapowiedź ewentualnych działań. Komisja wezwała Austrię, Polskę i Węgry, a także Czechy (które w maju 2016 r. wstrzymały wykonywanie relokacji) do bezzwłocznego rozpoczęcia relokacji. „Jeśli żadne działanie nie zostanie podjęte, w kolejnym raporcie w czerwcu 2017 r. Komisja sprecyzuje swoje stanowisko w odniesieniu do przysługujących jej na mocy Traktatu kompetencji, w szczególności w odniesieniu do wszczęcia procedur o naruszenie prawa" (ibid., s. 11). Już bowiem w pierwszym sprawozdaniu z funkcjonowania mechanizmu relokacji, Komisja Europejska wzywając państwa członkowskie do wypełnienia zobowiązań, zauważyła, że nawet wniesienie spraw do TS o dokonanie kontroli legalności decyzji z września 2015 r. (o czym szerzej w dalszej części tego tekstu) nie ma skutku zawieszającego. W odpowiedzi na dwunaste sprawozdanie Komisji, władze Austrii zainicjowały procedurę relokacji 50 osób przebywających we Włoszech. Przedstawiciele Polski i Węgier rozpoczęli zaś swoistą kampanię przeciw Komisji Europejskiej.

W obliczu zapowiedzi KE wszczęcia procedur o naruszenie prawa europejskiego, wiceminister spraw zagranicznych RP Konrad Szymański zaprezentował polskie stanowisko. Podkreślił, że w razie skierowania sprawy przeciw Polsce: ,[... ] jesteśmy przygotowani do konfrontacji opinii i swoich przekonań politycznych w tej sprawie [...] będziemy zwracali uwagę na to, że Polska jest jednym z 26 państw, które nie wykonują tej decyzji” (cyt. za: K. Szymański, 2017). Dodatkowo, podtrzymując odmowę wykonania decyzji o relokacji odwołał się do woli suwerena: „Jeżeli ktoś stawia sprawę w ten sposób, że próbuje Polaków stawiać pod murem, to ostateczną odpowiedzią jest referendum" (ibid.). Wypowiedź wiceministra Szymańskiego z kilku powodów zasługuje na krytyczną ocenę. Po pierwsze, wskazywanie, że postępowanie sądowe to miejsce wymiany poglądów politycznych, jest dowodem niezrozumienia lub nieznajomości istoty postępowania sądowego, w którym wynik zależy wyłącznie od siły argumentów prawnych. Po drugie, argument, iż 26 państw członkowskich nie wykonuje decyzji jest nieprawdziwy. Do 12 maja 2017 r. dwadzieścia dwa państwa członkowskie wykonały relokację w odniesieniu do 18418 osób (Report, 2017g, annex). Po trzecie, rozważając możliwość zorganizowania referendum, K. Szymański posłużył się twierdzeniem, iż KE „stawia Polskę pod murem”. We wrześniu 2015 r. Polska wyraziła zgodę na przyjęcie osób będących w oczywistej potrzebie ochrony międzynarodowej, zatem Komisja Europejska oczekuje jedynie wypełnienia przyjętych przez państwo zobowiązań. W końcu, wiceminister Szymański nie wziął pod uwagę, że kluczowe znaczenie dla ważności referendum ma $50 \%$ frekwencja.

Przedstawiciele Węgier argumentowali w podobny sposób. Zdaniem Ministra spraw zagranicznych Węgier Pétera Szijjártó, uruchomienie procedur o naruszenie prawa europejskiego w stosunku do państw odmawiajacych wykonania decyzji relokacyjnych to „szantaż i nieeuropejskie zachowanie”, a Komisja Europejska nadużywa przysługujące jej uprawnienia. „Nawet Komisja Europejska nie może odebrać państwu prawa do decydowania kogo wpuścić na swoje terytorium” (cyt. za: Czech Republic, 2017). 
W efekcie takiego stanowiska, choć w trzynastym sprawozdaniu opublikowanym w czerwcu 2017 r., Komisja Europejska odnotowała znaczący postęp w tempie relokacji, to wyraźnie podkreśliła naruszanie prawnego zobowiązania przez Polskę, Republikę Czeską i Węgry, które nie relokowały ani nie przesłały do Grecji i Włoch oficjalnych zobowiązań o gotowości do relokacji osób w potrzebie ochrony międzynarodowej (Report, 2017f, s. 2). Odnotowując brak odpowiedzi na wielokrotne wezwania do rozpoczęcia relokacji i realizacji postanowień decyzji z 14 i 22 września 2015 r., KE podjęła decyzję o wszczęciu procedur o naruszenie prawa europejskiego (ibid., s. 9). Uzasadnione opinie zostały w lipcu 2017 r. przesłane do władz Polski, Republiki Czeskiej i Węgier, które miały miesiąc na ustosunkowanie się do zarzutów ${ }^{11}$.

W trzynastym sprawozdaniu Komisja podniosła również, że Austria, która w maju 2017 r. złożyła oficjalne zobowiązanie do przyjęcia 50 takich osób przebywających we Włoszech, do chwili opublikowania raportu, nie wykonała tego obowiązku. KE zauważyła także, że choć Bułgaria, Estonia, Irlandia i Słowacja przyjmują na swoje terytoria osoby wymagające ochrony międzynarodowej, to nie relokowały ani jednej takiej osoby z Włoch (ibid., s. 5). Podając powody tej sytuacji, władze Estonii i Irlandii wskazały na konieczność przeprowadzania dodatkowych wywiadów z osobami mającymi zostać poddanymi relokacji, co wiązało się z wymogami bezpieczeństwa. W przypadku Bułgarii i Słowacji powodem były preferencje w relokowaniu określonych osób. Władze Bułgarii odmawiały przyjęcia obywateli Erytrei, zaś Słowacja wyraziła wolę relokowania jedynie samotnych kobiet z dziećmi i osób posiadających dokumenty podróży. Komisja uznała, że relokacja osób objętych mechanizmem uzgodnionym we wrześniu 2015 r. jest możliwa do wykonania do września 2017 r. i „powinna być naszym wspólnym celem, realizacją którego państwa członkowskie powinny wesprzeć sprawiedliwie i proporcjonalnie" (ibid., s. 8). Co istotne, podkreśliła, że choć decyzje w sprawie relokacji, podjęte we wrześniu 2015 r., przestaną obowiązywać 26 września 2017 r., to obowiązek relokowania wszystkich 160 tysięcy osób nie wygaśnie.

Czternaste sprawozdanie opublikowane pod koniec lipca 2017 r. powielało ustalenia dokonane przez Komisję Europejską miesiąc wcześniej. Odnotowano dalszy postęp w relokacji, podkreślając jednocześnie, że Polska i Węgry pozostają jedynymi państwami członkowskimi, które nie relokowały ani jednej osoby objętej nadzwyczajnym mechanizmem. Interesująco przedstawiała się sytuacja Austrii. Komisja kolejny raz zauważyła, że władze austriackie nie wykonały zobowiązania do relokacji osób przebywających we Włoszech i Grecji. Jednocześnie KE za wystarczające uznała złożenie przez Austrię trzech zobowiązań o gotowości do relokacji (w maju, czerwcu i lipcu 2017 r.) osób z Włoch, oczekując na ,niezwłoczne przekształcenie deklaracji w efektywną relokację" (Report, 2017c, s. 3). W odniesieniu do większości państw członkowskich za problematyczne Komisja Europejska uznała nieregularne tempo relokacji, opóźnienia

${ }^{11}$ W oficjalnym komunikacie polskiego MSZ poinformowano, że Polska wnosi o umorzenie przez KE toczącego się postępowania o naruszenie prawa europejskiego, gdyż „Polska nie zgadza się z logiką przyjętych we wrześniu 2015 r. decyzji relokacyjnych” (Komunikat, 2017a). Minister ds. europejskich Republiki Czeskiej w odpowiedzi na uzasadnioną opinię Komisji Europejskiej wskazał, że mechanizm relokacji uzgodniony we wrześniu 2015 r. nie funkcjonuje, nie przyczynia się do rozwiązania kryzysu migracyjnego, tworzy problemy dla bezpieczeństwa i nie daje możliwości przewidzenia ryzyka i kosztów (Czech government, 2017). 
w odpowiedzi na wezwania władz włoskich i greckich do przejęcia osób wymagających ochrony, a także wprowadzanie dodatkowych restrykcyjnych preferencji w odniesieniu do osób przebywających we Włoszech ${ }^{12}$.

Swoiste podsumowanie funkcjonowania mechanizmu relokacji stanowi piętnaste sprawozdanie Komisji Europejskiej. W okresie od października 2015 r. do końca sierpnia 2017 r. dokonano relokacji 27700 osób (Report, 2017b, s. 2) z przewidzianych 160 tysięcy (patrz: wykres 3). Do 27 września 2017 r. - według ustaleń KE - relokacji poddano 29144 osoby.

Wykres 3. Liczba osób poddanych relokacji w okresie od października 2015 do 31 sierpnia 2017 r.

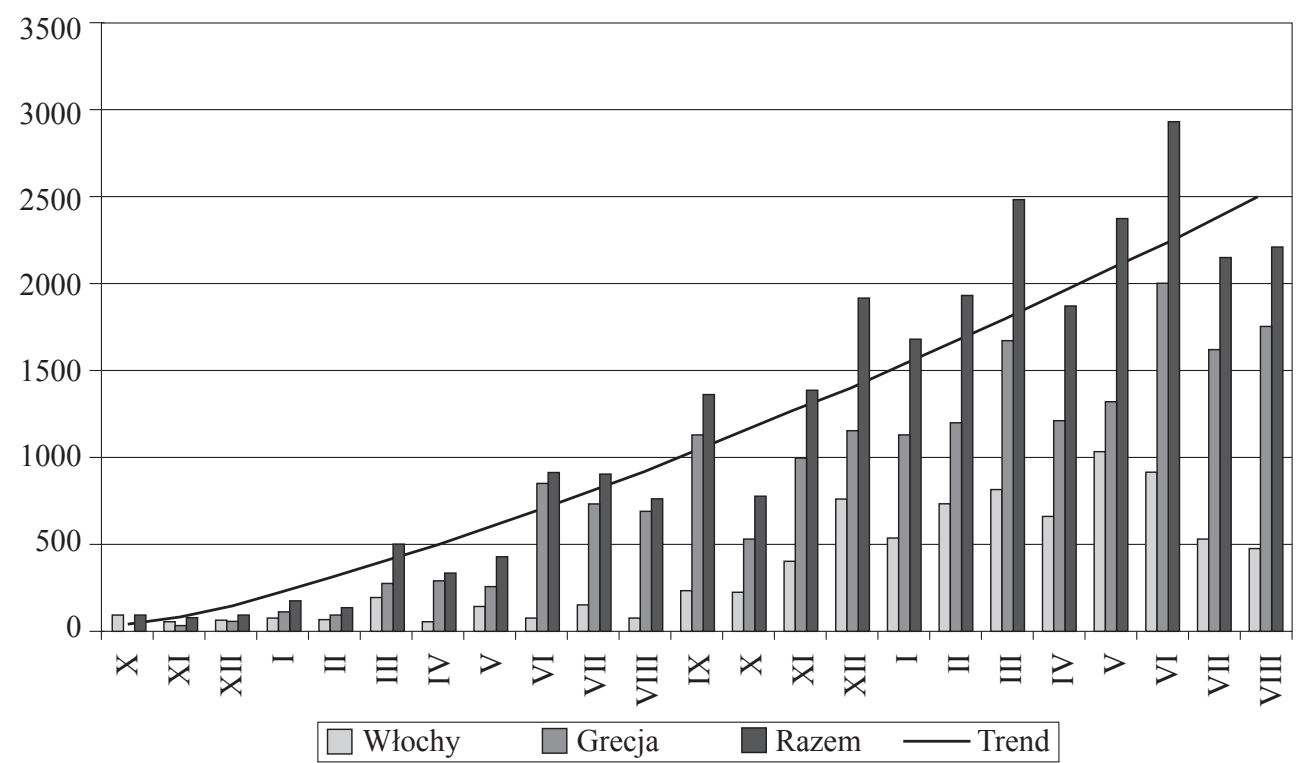

Źródło: Report, 2017b, s. 3.

Trudno zatem mówić o sukcesie w rozwiązywaniu kryzysu humanitarnego. Mechanizm zaprojektowany w celu odciążenia Grecji i Włoch i udzielenia pomocy zarówno tym dwóm państwom, jak i osobom wymagającym międzynarodowej ochrony, nie zadziałał tak, jak tego oczekiwano. $Z$ jednej strony, można mówić o niedopracowaniu mechanizmu, który nie odnosił się do procedury przyjmowania i rejestracji osób przybywających, pozostawiając ją w gestii państw członkowskich. Tymczasem właśnie różnice proceduralne często były przyczyną zahamowania relokacji. $Z$ drugiej, wskazać należy nieprzygotowanie Grecji i Włoch do szybkiej identyfikacji i rejestrowania napływających osób, co wstrzymywało pozostałe państwa w przejmowaniu odpowiedzialności za przybyszów. W końcu, niewielka skuteczność mechanizmu relokacji wynikała również z niewywiązywania się - przynajmniej części państw członkowskich - ze zobowiązań

${ }_{12}$ Dla przykładu, władze francuskie zadeklarowały możliwość przyjęcia jedynie rodzin lub samotnych kobiet z dzieckiem/dziećmi z obywatelstwem Erytrei. Patrz: Report, 2017c, s. 7. 
traktatowych (art. 80 TFUE), które w odniesieniu do polityki azylowej, imigracyjnej i polityki ochrony granic, wskazują na ponoszenie wspólnej odpowiedzialności i na solidarne podejście do problemów.

Mimo to inicjatywa relokacyjna, podjęta we wrześniu 2015 r., została oceniona pozytywnie przez Urząd Wysokiego Komisarza Narodów Zjednoczonych ds. uchodźców (UNHCR). System pozwolił na złagodzenie skutków kryzysu humanitarnego ,z jakim zmagała się Grecja, zmniejszył presję z jaką zmagały się Włochy i polepszył sytuację wielu osób poszukujących ochrony" (UNHCR calls, 2017). Pomimo formalnego zakończenia, zdaniem UNCHR mechanizm powinien być kontynuowany.

\section{Przyszłość systemu relokacji}

Uzgodniony we wrześniu 2015 r. nadzwyczajny, czasowy mechanizm relokacji zakończył funkcjonowanie 26 września 2017 r. Nie oznaczało to jednak końca relokacji, gdyż cele zakładające przejęcie odpowiedzialności za 160 tys. osób muszą być zrealizowane. Na takim stanowisku stanęła Komisja Europejska, która 6 września 2017 r. zyskała mocny argument w sporze z państwami odmawiającymi wykonania swych zobowiązań relokacyjnych.

6 września 2017 r. Trybunał Sprawiedliwości wydał orzeczenie w sprawach wniesionych przez Słowację i Węgry o kontrolę legalności decyzji z 22 września 2015 r. ustanawiającej nadzwyczajny, czasowy mechanizm relokacji cudzoziemców. Już tuż po wrześniowym głosowaniu minister spraw zagranicznych Węgier określił system relokacji mianem ,niewykonalnego, nierealnego, nonsensownego”, a premier Słowacji wskazał: ,sprzeciwialiśmy się temu nonsensowi od początku i jako suwerenne państwo mamy prawo wniesienia pozwu" (cyt. za: Nolan, 2015). W grudniu 2015 r. oba państwa skierowały sprawę do TS. Władze Słowacji domagały się uznania decyzji z 22 września 2015 r. za niewywołującą skutków prawnych, zaś władze Węgier - uznania tej samej decyzji za niewywołującą skutków prawnych lub za niewywołującą skutków prawnych w odniesieniu do Węgier (Judgment, 2017, par. 32-33). Z prawa interwencji procesowej skorzystała Polska. Po stronie stającej przed Trybunałem Rady opowiedzieli się jako interwenienci procesowi: Belgia, Francja, Grecja, Luksemburg, Niemcy, Szwecja i Włochy oraz Komisja Europejska.

Odnosząc się do zarzutu, iż decyzja z 22 września 2015 r. została przyjęta przy wykorzystaniu niewłaściwej procedury prawnej, sędziowie stwierdzili, że procedura nieustawodawcza mogła być zastosowana. Zdaniem Trybunału, Traktat o funkcjonowaniu Unii Europejskiej gwarantuje możliwość wykorzystania takiej procedury w sprawach szczególnych, wskazanych w traktatach (ibid., par. 61). Traktat zapewnia taką możliwość w odniesieniu do wspólnej polityki azylowej w przypadku kryzysów migracyjnych (ibid., par. 74). Zatem masowy napływ cudzoziemców na terytoria państw członkowskich dawał możliwość zastosowania wszelkich środków tymczasowych, które stanowić będą szybką i skuteczną reakcję na taką nadzwyczajną sytuację. W odpowiedzi na zarzut, iż przedmiotowa decyzja nie przyczyni się do osiągnięcia celu w jakim została przyjęta, sędziowie wskazali, że ustanowiony nadzwyczajny i czasowy mechanizm relokacji służyć ma wspomożeniu Grecji i Włoch w radzeniu sobie z nadzwyczajną sytuacją, cha- 
rakteryzującą się nagłym napływem obywateli państw trzecich, będących w oczywistej potrzebie ochrony międzynarodowej. Mechanizm relokacji uznali za jeden ze środków przyjętych dla wsparcia systemów azylowych wskazanych państw (obok wsparcia operacyjnego i finansowego) i dlatego musi być analizowany w uwzględnieniem pozostałych rozwiązań przyjętych przez Radę w odpowiedzi na kryzys migracyjny. Sędziowie podkreślili, że mała liczba dokonanych do tej pory relokacji, nie jest dowodem na nieskuteczność samego mechanizmu, co utrzymywali skarżący, lecz jest powodowana wieloma czynnikami, ,włączając w to w szczególności brak współpracy pewnych państw członkowskich" (ibid., par. 223).

Odnosząc się do zarzutu, iż decyzja z 22 września 2015 r. stanowi naruszenie wyrażonej w Traktacie o Unii Europejskiej zasady proporcjonalności, Trybunał uznał, że przedmiotowa decyzja ma wpływ na sytuację wszystkich państw relokacji i wymaga równowagi między różnymi interesami, lecz na pierwszym miejscu należy mieć na uwadze cel w jakim decyzja została przyjęta. $Z$ tego względu nie można uznać, że uwzględnienie sytuacji ogólnej, a nie sytuacji pojedynczych państw członkowskich jest sprzeczne z zasadą proporcjonalności (ibid., s. 290). W sytuacji, gdy jedno z państw członkowskich mierzy się z nadzwyczajną sytuacją w rozumieniu Traktatu o funkcjonowaniu Unii Europejskiej (art. 78.3), obciążenie wynikające $z$ decyzji o ustanowieniu środków tymczasowych musi - co do zasady - być rozdzielone między pozostałe państwa członkowskie zgodnie z zasadą solidarności i sprawiedliwego podziału odpowiedzialności, która odnosi się do polityki azylowej (art. 80 TFUE) (ibid., par. 291). Dodatkowo, zachowanie zasady proporcjonalności gwarantują różnorodne mechanizmy dostosowawcze, przewidziane w przedmiotowej decyzji. Jak wskazali sędziowie TS, skarżący - szczególnie Węgry - mogli wnioskować do Rady o czasowe zawieszenie obowiązku relokacji (jak uczyniły to Austria i Szwecja). Co więcej, zdaniem sędziów, zasadę proporcjonalności pozwala zachować współczynnik relokacji wskazany w decyzji. Określony został przy użyciu kryteriów obiektywnych i mierzalnych, uwzględniających sytuację każdego państwa członkowskiego (szerzej: Potyrała, 2015, s. 37) ${ }^{13}$.

Uwzględniając powyższe, Trybunał Sprawiedliwości postanowił oddalić obie skargi, co oznaczało potwierdzenie prawnego obowiązku dokonania relokacji, spoczywającego na państw członkowskich. Premier Słowacji wydał oświadczenie o po-

${ }^{13}$ W tym miejscu warto przytoczyć opinię sędziów na temat argumentu wyrażonego przez Polskę w ramach interwencji procesowej. Zdaniem przedstawicieli Polski, kwoty ustalone w decyzji z 22 września 2015 r. wywierają różny, nieproporcjonalny wpływ na państwa członkowskie. Niektóre państwa członkowskie muszą ponieść większy ciężar goszczenia niż inne. Chodzi o państwa, które są , homogeniczne etnicznie, jak Polska” i których społeczności różnią się kulturowo i językowo od osób relokowanych. Zdaniem Trybunału argument ten nie mógł być uwzględniony z trzech powodów. Po pierwsze, wykraczał poza ramy przedmiotowe wniosku węgierskiego (który odnosił się wyłącznie do sytuacji Węgier, a Polska korzystała wyłącznie z prawa interwencji procesowej). Po drugie, gdyby relokacja uzależniona była od istnienia więzi etnicznych czy językowych, to taki mechanizm naruszałby wyrażoną w Traktacie zasadę solidarności w rozwiązywaniu kryzysów migracyjnych. Po trzecie, rozważania na temat pochodzenia etnicznego osób ubiegających się o ochronę międzynarodową są wyraźnie sprzeczne z prawem europejskim, w szczególności z artykułem 21 Karty Praw Podstawowych (Judgment, 2017, par. 302-305. Wskazać można również sprzeczność rozważań tego typu z art. 10 TFUE, wskazującym że przy określaniu i realizacji polityk UE dąży do zwalczania wszelkiej dyskryminacji, w tym ze względu na pochodzenie etniczne). 
szanowaniu dla decyzji trybunału z jednoczesnym zastrzeżeniem, że „nie zmienia ono naszego przekonania, że kwotowa relokacja uchodźców nie funkcjonuje w praktyce" (Stowacja: szanujemy, 2017). Minister spraw zagranicznych Węgier określił decyzję trybunału mianem „oburzającego i nieodpowiedzialnego” oraz „zagrażającego bezpieczeństwu i przyszłości Europy” (ibid.). Premier Węgier podkreślił, że decyzja TS nie jest czynnikiem, który może wpłynąć na zmianę stanowiska Węgier. W podobnym tonie wypowiedziała się ówczesna premier rządu RP. Wskazała, że Polska spodziewała się takiego rozstrzygnięcia, lecz „nie zmienia ono absolutnie stanowiska polskiego rządu" (Szydło, 2017).

Decyzja Trybunału Sprawiedliwości potwierdzająca prawne zobowiązanie państw członkowskich do dokonania relokacji wzmocniła stanowisko Komisji Europejskiej wyrażone w sprawozdaniach z realizacji relokacji. 7 grudnia 2017 r. Komisja Europejska wniosła sprawy do TS przeciw odmawiającym relokacji: Republice Czeskiej, Polsce i Węgrom, zgodnie z wcześniejszymi zapowiedziami sygnalizowanymi w sprawozdaniach $^{14}$. Była to naturalna konsekwencja procedur zainicjowanych przez Komisję wobec tych państw w czerwcu 2017 r. oraz decyzji TS z września 2017 r. ${ }^{15}$

Tego samego dnia, 7 grudnia 2017 r. Komisja Europejska zaprezentowała nowa, poprawioną wersję reformy Wspólnego europejskiego systemu azylowego i wspólnej polityki imigracyjnej.

Pierwotna propozycja z maja 2016 r. przewidywała ustanowienie stałego i obowiązkowego mechanizmu relokacji, który w razie kryzysu migracyjnego byłby uruchamiany automatycznie. Za pomysłem tym optował Parlament Europejski. Większość państw członkowskich sprzeciwiła się jednak tej propozycji. Szczególnie aktywnie głos zabierali członkowie Grupy Wyszehradzkiej, podkreślający, że „rozwiązania wprowadzające obowiązkową relokację migrantów, niezależnie czy bazujące na decyzjach o charakterze ad hoc, czy na stałym mechanizmie, nie mogą być uznane za efektywne [...]" (Joint, 2016b). Na szczycie Unii Europejskiej w Bratysławie wszystkie państwa Grupy Wyszehradzkiej wsparły pomysł kompromisu w sprawie uchodźców. Ich zdaniem rozwiązanie stanowić może zasada elastycznej solidarności (ang. flexible solidarity): „ta koncepcja powinna umożliwić państwom członkowskim decydowanie o określonych formach wkładu, uwzględniając ich doświadczenia i możliwości" (Joint, 2016a).

Brak szans na powodzenie reformy bazującej na stałym mechanizmie relokacji osób wymagających ochrony międzynarodowej, skłonił Komisję Europejską do zaprojektowania systemu hybrydowego. Stworzenie stabilnego systemu azylowego wymaga - zdaniem Komisji - bardziej efektywnego i sprawiedliwego podejścia bazującego na

${ }^{14} \mathrm{~W}$ oczekiwaniu na wyrok trybunału, przedstawiciele niektórych państw członkowskich, a nawet reprezentanci Unii Europejskiej zaczęli rozważać możliwość nałożenia swoistego rodzaju sankcji finansowych na państwa niewykonujące zobowiązań relokacyjnych. Spekulacje te przeciął Jean-Claude Juncker, którego zdaniem „wykorzystywanie sankcji budżetowych przeciw krajom sprzeciwiającym się przyjmowaniu uchodźców jest z założenia złym środkiem” (Juncker przeciw, 2018).

${ }_{15}$ W oficjalnym komunikacie z 7 grudnia 2017 r. polskie MSZ podkreśliło, że Polska ,jest przygotowana do obrony swojego stanowiska przed Trybunałem Sprawiedliwości UE [...] żadne z państw członkowskich nie wywiązało się z nałożonych na nie zobowiązań" (Komunikat, 2017b). Zdaniem MSZ Węgier obowiązkowe kwoty relokacji są niemożliwe do implementowania i stanowią naruszenie prawa europejskiego (Refugee, 2017). 
zasadach solidarności i odpowiedzialności, zgodnie z postanowieniami traktatowymi. We wspólnym systemie azylowym i na obszarze Schengen bez kontroli na granicach wewnętrznych „nie może istnieć jeden bez innych” (Communication, 2017, s. 6). Doświadczenia lat ubiegłych pokazały jednak, że najbardziej kontrowersyjnym elementem reformy jest mechanizm relokacji. $Z$ tego względu Komisja proponuje, aby w sytuacjach nadzwyczajnych (do których odnosi się TFUE) uruchamiany był obowiązkowy mechanizm relokacji, zaś w ,mniej trudnych” sytuacjach relokacja powinna być dokonywana na zasadzie dobrowolności (ibid.). W takich przypadkach solidarność może przejawiać się w różnych formach. Podejście hybrydowe jest więc kompromisem, w którym Komisja wychodzi naprzeciw oczekiwaniom państw członkowskich, wiedząc że tym razem nie ma możliwości nakłonienia państw do pierwotnych propozycji i uzyskania większości głosów za stałym, automatycznym mechanizmem relokacji. Warto jednak zwrócić uwage na ważny aspekt założeń reformy: to Komisja Europejska ma być uprawniona do stwierdzania jaki charakter przybrał dany kryzys migracyjny i jakie środki zaradcze powinny być podjęte. Jeśli dobrowolne działania państw członkowskich nie doprowadzą do zakończenia kryzysu, wówczas Komisja będzie postulowała o uruchomienie mechanizmu obowiązkowego. Decyzja zapadać będzie w głosowaniu większościowym na forum Rady.

$$
* * *
$$

Artykuł 80 Traktatu o funkcjonowaniu Unii Europejskiej wskazuje wyraźnie, że polityki dotyczące kontroli granicznej, azylu i imigracji ,,podlegają zasadzie solidarności i sprawiedliwego podziału odpowiedzialności między Państwami Członkowskimi [...]”. Przejawem praktycznej realizacji obu zasad miał być system relokacji uzgodniony we wrześniu 2015 r. Solidarność nakazywała udzielenie pomocy władzom Grecji i Włoch, zmagającym się z masowym napływem obywateli państw trzecich. Sprawiedliwy podział odpowiedzialności zapewnić miał współczynnik relokacji uwzględniający sytuację państw członkowskich.

I choć Komisja Europejska - pomysłodawczyni mechanizmu relokacji - z chwilą zakończenia projektu uznała, że system „funkcjonuje i przynosi efekty” (European, 2017) i pomimo kontrowersji odnotowano ,solidny postęp” (State of the Union, 2017), to nie można nie zauważyć, że efekty te dalekie są od oczekiwań. Oczywiście trend jest wzrostowy - liczba cudzoziemców relokowanych z Grecji i Włoch rośnie, jednak ze 160 tysięcy osób objętych mechanizmem relokacji, w ciągu dwóch lat obowiązywania systemu odpowiedzialność przejęto zaledwie za nieco ponad 30 tysięcy. Celu nie udało się zatem zrealizować, a postęp - wbrew opinii J. C. Junckera - z pewnością nie jest solidny. Traktatowe odniesienia do solidarności okazały się dla wielu państw członkowskich czysto deklaratywne: albo otwarcie sprzeciwiły się wykonaniu zobowiązań relokacyjnych, albo relokację opóźniały, powołując się na ochronę bezpieczeństwa i/lub porządku wewnętrznego.

Pomimo formalnego zakończenia okresu obowiązywania decyzji o relokacji z września 2015 r., obowiązek rozdzielenia osób wymagających ochrony międzynarodowej nie wygasł. Wszystkie osoby wymagające ochrony międzynarodowej, które dotarły do 
Grecji lub Włoch przed 26 września 2017 r. muszą być poddane relokacji. Z tego względu, wniesienie przez Komisję Europejską do Trybunału Sprawiedliwości spraw przeciw trzem państwom odmawiającym wykonania decyzji o relokacji, było działaniem możliwym do przewidzenia. Jest to też czytelny sygnał mający nakłonić do aktywnego działania pozostałe państwa, które choć relokacji dokonuja, to w skali odbiegającej znacząco od ustalonych w 2015 r. kwot. Niezależnie jednak od oceny dokonanej przez Komisję Europejską, niezależnie od oczekiwanych wyroków TS, zreformowany Wspólny europejski system azylowy nie będzie oparty o stały mechanizm relokacji. Przeciwników takiego rozwiązania wśród państw członkowskich jest wielu, a uzasadnień dla sprzeciwu wobec takiego rozwiązania również nie zabraknie: ochrona bezpieczeństwa państwa i obywateli, ochrona porządku wewnętrznego, w końcu przywołany zostanie argument suwerenności, której jednym z przejawów jest wyłączne prawo państwa do decydowania o udzieleniu lub odmowie udzielenia cudzoziemcowi prawa wjazdu. Zobowiązania wobec osób poszukujących azylu - umocowane w prawie międzynarodowym tj. w Konwencji dotyczącej statusu uchodźców, której stronami są wszyscy członkowie UE - zejdą na plan dalszy.

\section{Bibliografia}

Adamczyk A. (2017), Solidarność europejska a relokacja osób wymagajacych ochrony międzynarodowej, ,Przegląd Zachodni”, nr 2, s. 47-54.

Communication from the Commission to the European Parliament, the European Council and the Council. Commission contribution to the EU Leaders' thematic debate on a way forward on the external and internal dimension of migration policy (2017), COM (2017) 820 final, 7.12.2017, Brussels.

Communication from the Commission to the European Parliament, the European Council and the Council. Eighth report on relocation and resettlement (2016a), COM (2016) 791 final, 8.12.2016, Brussels.

Communication from the Commission to the European Parliament, the European Council and the Council. Fifth report on relocation and resettlement (2016b), COM (2016) 480 final, 13.07.2016, Brussels.

Communication from the Commission to the European Parliament, the European Council and the Council. First report on relocation and resettlement (2016c), COM (2016) 165 final, 16.03.2016, Brussels.

Communication from the Commission to the European Parliament, the European Council and the Council. Fourth report on relocation and resettlement (2016d), COM (2016) 416 final, 15.06.2016, Brussels.

Communication from the Commission to the European Parliament, the European Council and the Council. Seventh report on relocation and resettlement (2016e), COM (2016) 720 final, 9.11.2016, Brussels.

Communication from the Commission to the European Parliament, the European Council and the Council. Sixth report on relocation and resettlement (2016f), COM (2016) 636 final, 28.09.2016, Brussels.

Communication from the Commission to the European Parliament, the European Council and the Council. Third report on relocation and resettlement (2016g), COM (2016) 360 final, 18.05.2016, Brussels. 
Czech government insists migration controls should precede relocation demands (2017), Euractiv, 24.07.2017, https://www.euractiv.com/section/development-policy/news/czechs-insist-migration-controls-should-precede-relocation-demands/, 20.01.2018.

Czech Republic, Hungary, Poland face EU sanctions on migrants (2017), EU Observer, 13.06.2017, https://euobserver.com/migration/138216, 20.01.2018.

European Agenda on Migration: Good progress in managing migration flows need to be sustained (2017), European Commission Press Release, Brussels, 6.09.2017, http://europa.eu/rapid/ press-release_IP-17-3081_en.htm, 27.11.2017.

Joint Statement of the Heads of Governments of the V4 Countries (2016a), 16.09.2016, Bratislava, http://www.visegradgroup.eu/documents/official-statements, 15.03.2017.

Joint Statement of V4 Interior Ministers on the Establishment of the Migration Crisis Response Mechanism (2016b), Warsaw, 21.11.2016, http://www.visegradgroup.eu/documents/official-statements, 15.03.2017.

Juncker przeciw konsekwencjom pieniężnym dla nieprzyjmujacych uchodźców (2017), Interia fakty, 7.02.2018, http://fakty.interia.pl/raporty/raport-unia-europejska/aktualnosci/news-junckerprzeciw-konsekwencjom-pienieznym-dla-nieprzyjmujacyc,nId,2505200?hkt=facts-1\#iwa source=bloczek_poczta, 20.01.2018.

Judgment of the Court (Grand Chamber). Joint Cases C-643/15 and C-647/15 (2017), 6.09.2017, http://curia.europa.eu/juris/document/document.jsf?text=\&docid=194081\&pageIndex $=0 \&$ doc lang=en\&mode $=1$ st\&dir $=\& o c c=$ first\&part $=1 \& \mathrm{cid}=1014408,20.01 .2018$.

Komunikat MSW w sprawie przekazania do Komisji Europejskiej odpowiedzi na uzasadnionq opinie w zwiazku z niewypetnieniem zobowiqzań wynikajacych z decyzji relokacyjnych (2017a), MSZ, 23.08.2017, http://www.msz.gov.pl/pl/aktualnosci/wiadomosci/komunikat_msz_w_sprawie_ przekazania_do_komisji_europejskiej_odpowiedzi_na_uzasadniona_opinie_w_zwiazku_z_ niewypelnieniem_zobowiazan_wynikajacych_z_decyzji_relokacyjnych_, 23.09.2017.

Komunikat MSZ ws. wniesienia skarg przed Trybunat Sprawiedliwości UE (2017b), MSZ, 7.12.2017, http://msz.gov.pl/pl/p/msz_pl/c/MOBILE/aktualnosci/wiadomosci/komunikat_msz_ws wniesienia_skarg_przed_trybunal_sprawiedliwosci_ue_przeciwko_polsce_czechom_i_ wegrom_w_zwiazku_z_niewykonaniem_przez_te_kraje_decyzji_relokacyjnych_z_ wrzesnia_2015_r_, 20.01.2018.

K. Szymański: Nie widzimy możliwości kompromisu w sprawie uchodźców. Jesteśmy gotowi spotkać sie z KE w sqdzie (2017), RadioZet.pl, 19.05.2017, http://www.radiozet.pl/Radio/Programy/ Gosc-Radia-ZET/Gosc-Radia-ZET-Konrad-Szymanski-u-Konrada-Piaseckiego-19-05-2017r, 19.05.2017.

Nolan D. (2015), Refugee crisis: EU divided as Hungary attacks migrant quota as 'unrealisable and nonsense', „The Telegraph”, 23.09.2015.

Political roadmap for a sustainable migration policy (2017), European Commission News, Brussels, 7.12.2017, https://ec.europa.eu/commission/news/political-roadmap-sustainable-migrationpolicy-2017-dec-07_en, 11.12.2017.

Potyrała A. (2016), Kryzys uchodźczy a przyszłość unijnego systemu azylowego, w: Uchodźcy w Europie - uwarunkowania, istota, nastęstwa, red. K. A. Wojtaszczyk, A. Szymańska, Warszawa.

Potyrała A. (2015), W poszukiwaniu solidarności. Unia Europejska wobec kryzysu migracyjnego 2015, „Przegląd Politologiczny”, nr 4, ss. 33-52.

Refugee relocation referral adds to Hungary's legal woes (2017), „Budapest Business Journal”, 7.12.2017, https://bbj.hu/politics/refugee-relocation-referral-adds-to-hungarys-legal-woes_142669, 20.01.2018.

Report from the Commission to the European Parliament, the European Council and the Council. Eleventh report on relocation and resettlement (2017a), COM (2017) 212 final, 12.04.2017, Brussels. 
Report from the Commission to the European Parliament, the European Council and the Council. Fifteenth report on relocation and resettlement (2017b), COM (2017) 465 final, 6.09.2017, Brussels.

Report from the Commission to the European Parliament, the European Council and the Council. Fourteenth report on relocation and resettlement (2017c), COM (2017) 405 final, 26.07.2017, Brussels.

Report from the Commission to the European Parliament, the European Council and the Council. Ninth report on relocation and resettlement (2017d), COM (2017) 74 final, 8.02.2017, Brussels.

Report from the Commission to the European Parliament, the European Council and the Council. Second report on relocation and resettlement (2016), COM (2016) 222 final, 12.04.2016, Brussels.

Report from the Commission to the European Parliament, the European Council and the Council. Tenth report on relocation and resettlement (2017e), COM (2017) 202 final, 2.03.2017, Brussels.

Report from the Commission to the European Parliament, the European Council and the Council. Thirteenth report on relocation and resettlement (2017f), COM (2017) 330 final, 13.06.2017, Brussels.

Report from the Commission to the European Parliament, the European Council and the Council. Twelfth report on relocation and resettlement (2017g), COM (2017) 260 final, 16.05.2017, Brussels.

Rozporzqdzenie Rady Ministrów w sprawie relokacji cudzoziemców w roku 2016. Projekt z 12 stycznia 2016 r. (2016), https://bip.mswia.gov.pl/bip/projekty-aktow-prawnyc/2016/23860,Projektrozporzadzenia-Rady-Ministrow-w-sprawie-relokacji-cudzoziemcow-w-roku-20.html, 23.03.2016.

Slowacja: szanujemy decyzję Trybunatu. Węgry: jest oburzajaca (2017), TVN24, 6.09.2017, https:// www.tvn24.pl/wiadomosci-ze-swiata,2/premier-slowacji-szanujemy-decyzje-trybunalu-wsprawie-relokacji,770470.html, 7.09.2017.

State of the Union-Commission presents next steps towards a stronger, more effective and fairer EU migration and asylum policy (2017), European Commission Press Release, Brussels, 27.09.2017, http://europa.eu/rapid/press-release_IP-17-3406_en.htm, 27.11.2017.

Szydto po decyzji o relokacji: spodziewaliśmy się, ale to nie zmienia stanowiska rzqdu (2017), TVN24, 6.09.2017, https://www.tvn24.pl/wiadomosci-z-kraju,3/premier-szydlo-o-relokacji-uchodzcow-i-decyzji-tsue, 770502.html, 7.09.2017.

Traktat o funkcjonowaniu Unii Europejskiej, Lizbona 2007. Wersja skonsolidowana (2012), Dz. U. UE C 326, 26.10.2012.

UNHCR calls for the EU relocation scheme to continue (2017), 26.09.2017, http://www.unhcr.org/ news/press/2017/9/59ca64354/unhcr-calls-eu-relocation-scheme-continue.html, 13.11.2017.

\section{Relocation mechanism in the reports of the European Commission. Evaluation and perspectives}

\section{Summary}

On September 26, 2017, the decisions concerning the relocation of persons in clear need of international protection formally ceased to bind. Until that time, out of 160,000 persons, only 29,000 have been relocated. With the application of two academic methods (that of legal analysis and analysis of political decisions), the following research questions are addressed in this paper: (1) what were the reasons of some member states to refuse relocation?; (2) what actions have been taken by the European 
Commission to persuade member states to fulfill their legal obligations?; (3) what are the consequences of non-compliance with legal obligations to relocate persons in need of international protection? The paper presents an analysis of the European Commission's monthly reports on relocation. The reasons for member states' non-compliance with their legal obligations and for their reluctance to reform the EU asylum and immigration policy have been pointed out. The analysis demonstrates that EU member states have given priority to state security, setting aside the principle of solidarity and fair sharing of responsibility in migration and asylum policies, stipulated in EU treaties.

Key words: relocation, European Union, reports of the European Commission 